\title{
Stream order-dependent diversity metrics of epilithic diatom assemblages
}

\author{
Csilla Stenger-Kovács • Lívia Tóth • \\ Franciska Tóth · Éva Hajnal · Judit Padisák
}

Received: 3 May 2013/Revised: 25 July 2013/Accepted: 26 July 2013/Published online: 7 August 2013

(C) Springer Science+Business Media Dordrecht 2013

\begin{abstract}
Diatoms are considered as an appropriate indicator group for ecological status assessment of surface waters. These organisms can be indicative not only of the waterchemical but also of the hydromorphological characteristics (e.g., stream size, physical habitat diversity) of running waters. In this study, diatom diversity metrics (species number, Shannon diversity, and evenness) from 506 sites in Pannon ecoregion (Hungary) were compared to the Strahler stream order system established with ArcView GIS 3.2. SOM analyses were performed to exclude the effect of nutrients on diversity metrics along the stream orders. Mixed-effects linear models and
\end{abstract}

Handling editor: Luigi Naselli-Flores

C. Stenger-Kovács $(\bowtie) \cdot$ L. Tóth · J. Padisák

Department of Limnology, University of Pannonia,

Egyetem u. 10, Veszprém 8200, Hungary

e-mail: stenger.kovacs@almos.uni-pannon.hu

C. Stenger-Kovács · J. Padisák

HAS-UP Limnoecology Research Group of the Hungarian Academy of Sciences, Egyetem u. 10, Veszprém 8200, Hungary

F. Tóth

Geoinformatics Research Group, Department of Physical Geography, Eötvös Loránd University, Egyetem tér 1-3, Budapest 1053, Hungary

É. Hajnal

Alba Regia University Center Székesfehérvár, Óbuda University, Budai út. 45, Székesfehérvár 8000, Hungary
Tukey's post hoc test revealed a linear relationships between species number, diversity and stream orders on ecoregion level from first- to eighth-order streams. The species number increases with an average of $8 \%$, and the diversity by $10 \%$ per unit increase of the stream order. However, we could not find relationships with evenness. Autotrophic diversity metrics based on diatom species data appear to increase parallel with the stream order while those of heterotrophic metrics (published in the literature) maximize at medium stream orders. We argue that stream order is a relevant typological parameter which can basically determine the diatom diversity metrics, and it is well applicable in biomonitoring.

Keywords Stream order - Diatom . Biomonitoring - Species number - Diversity · ArcView · Water Framework Directive

\section{Introduction}

Water body size is one of the most important factors determining the structure and function of aquatic ecosystems. However, it is difficult to define in absolute terms either in the field or in a geographic information system (Hughes et al., 2011). The Strahler stream order (Strahler, 1957) has been a useful indicator of stream size in stream biology (Miyamoto et al., 2011) regionally, nationally, and globally. It is a useful descriptor of the catchment area, distance from 
the source, and the mean annual discharge (Hughes et al., 2011). Stream order may separate streams into different segments with similar internal characteristics (Seyfer \& Wilhm, 1977). Several studies were published where stream order was used to classify and explain diversity and composition of lotic- [like macroinvertebrates (e.g., Pringle, 1985), phytoplankton (e.g., Garnier et al., 1995), fish (e.g., McCormick et al., 2000)] and riparian organisms (e.g., Dunn et al., 2011), and even the water quality (Crunkilton \& Duchrow, 1991). Stream order has been successfully applied in freshwater biodiversity planning (Higgins et al., 2005).

So far, there has been no systematic attempt at studying the response of diversity of diatom communities to changes in stream order in Europe, although the investigation of benthic diatoms received distinguished interest in implementation of the Water Framework Directive (WFD) (EC, 2000) since most of the member states chose diatoms as proxies for phytobenthos (Kelly et al., 2009a). Only some publications can be found in the USA (Cushing et al., 1983; Molloy, 1992) about stream size and stream orderdependent diatom species compositions and morphological growth forms (ecological guilds). Stream order as an important component of understanding relationship between diatom assemblages and eutrophication/ organic pollution was considered by Rott et al. (1998) in the Grand River (Ontario) and by as Pan et al. (1996) in a water basin consisted of 49 streams from 1 st to 3 rd order. Potapova \& Charles (2002) found that the stream size is a major element in determining diatom assemblages in rivers. According to Leira \& Sabater (2005), variation of the diatom assemblages can be explained not only by chemical characteristics but also by physiographical factors: thus, stream order may serve as a general descriptor summarizing the physical habitat. At large spatial scales, variation in diatom assemblages along stream longitudinal gradients is attributable to three main reasons: changes in morphology, in geology, and in land use of streams and their basins (Molloy, 1992). According to Kutka \& Richards (1996) diatoms can be suitable indicators of stream physical characteristics for monitoring purposes. Present knowledge about the variation of diatom composition along stream order gradients on a larger basin or landscape level has been limited. This applies also for ecoregions which serve as basis of ecological status assessment of the WFD.
In our research, diatom composition was analyzed in running waters of Pannon Ecoregion covering all of Hungary. Relationship between typological classification (Strahler rank) and diatom assemblages increases from class to order resolution and saturates at the finest levels (species and subspecies; Rimet \& Bouchez, 2012). Therefore, diatom diversity metrics based on species data (species number, diversity, evenness) of Hungarian rivers and stream order data were collected to analyze this relationship. Our hypotheses were that (i) there is clear, positive, linear relationship between species number/Shannon diversity/evenness and stream order separately, and (ii) species number and diversity values are characteristic for a given stream order, indicate the hydro-morphological status of the running waters.

\section{Methodology}

Benthic diatom data included in the PERIDAT Diatom Database (Hajnal et al., 2010) were used in this study. These data derive from different sources (i) ECOSURV project (van Dam et al., 2005), (ii) thesis works (e.g., Kiss, 2004; Kovács, 2006), and (iii) publications of University of Pannonia, Department of Limnology (e.g., Pór et al., 2000; Kovács et al., 2004, 2005). Altogether 683 sampling sites were included in this study. Epilithic diatom sampling, identification, and quantification followed standard methods (Kelly et al., 1998; CEN, 2003). Diversity values were calculated by the widely used Shannon-Weaver function (Shannon \& Weaver (1949). The stream order was determined after the accurate identification and location of different sampling sites (Rostetter, 2009) using ArcView GIS geographic information system, EOV coordinates and cartographs according to HortonStrahler (Gordon et al., 1994). Of the 683 samples, it was possible to determine the stream order precisely in 506 cases (Fig. 1); these samples were taken at 357 different sampling sites in 189 streams (number of repeated samples per sampling site ranged 1-25, mean $\pm \mathrm{SD}=1.47 \pm 1.81$ ). To investigate the clustering and gradient features of the data, the selforganizing methods with SOM Toolbox of MATLAB software were applied (Vesanto \& Alhoniemi, 2000). The first was supplemented with the weight matrix principal component projection. For the test, 117 randomly chosen samples were used from stream 
orders 1 to 8 (stream order $1-41$ samples, stream order 2-22 samples, stream order 3-27 samples, stream order $4-8$ samples, stream order 5-3 samples, stream order $6-2$ samples, stream order $7-3$ samples, stream order 8-11 samples). The Kohonen type self-organizing map analysis was executed both on ecological features (species number, diversity, evenness) and on water chemical data $\left(\mathrm{NH}_{4}{ }^{+}, \mathrm{NO}_{2}{ }^{-}\right.$, $\mathrm{NO}_{3}{ }^{-}$, and total $\mathrm{P}$ ) with hexagonal topology and equalized mask to show nutrients can influence the diversity metrics along the stream order. To analyze the relationship of stream order with number of species, diversity, and evenness, we used mixedeffects linear models in $\mathrm{R}$ statistical and computing environment ( $\mathrm{R}$ 2.11.0, R Development Core Team, 2010). The effect of stream order was modeled by linear regression whereas the non-independence of samples taken at the same site and in the same stream, respectively, was taken into account by using hierarchical random factors, i.e., sampling site nested in stream. Then Tukey's post hoc tests were used to compare samples with different stream order pairwise.

\section{Results}

The investigated Hungarian running waters represent first- to eighth-order rivers. Most of the sampling sites were first (317) and second (128) order. The number of the higher order streams was smaller. Eighth-order streams were represented (11 sites, $2.2 \%$ of the dataset) exclusively by the different sections of the Danube River; Table 1).

The average species number of the first-order streams was $23 \pm 7$ (average \pm standard deviation) and that of the eighth-order rivers was $44 \pm 16$. The average diversity of the first-order streams $(2.73 \pm 0.67)$ increased gradually until it reached $3.75 \pm 0.81$ in the eighth-order river. The evenness of streams varied from $0.48 \pm 0.05$ (fifth-order) to $0.73 \pm 0.27$ (second-order) (Table 1).

The self-organizing map of ecological data u_matrix does not show any clear clustering by the stream order, but a clear gradient in species number of the samples and the diversity values (map size $11 * 5$, final quantization error $q_{0}=0.368$, final topographic

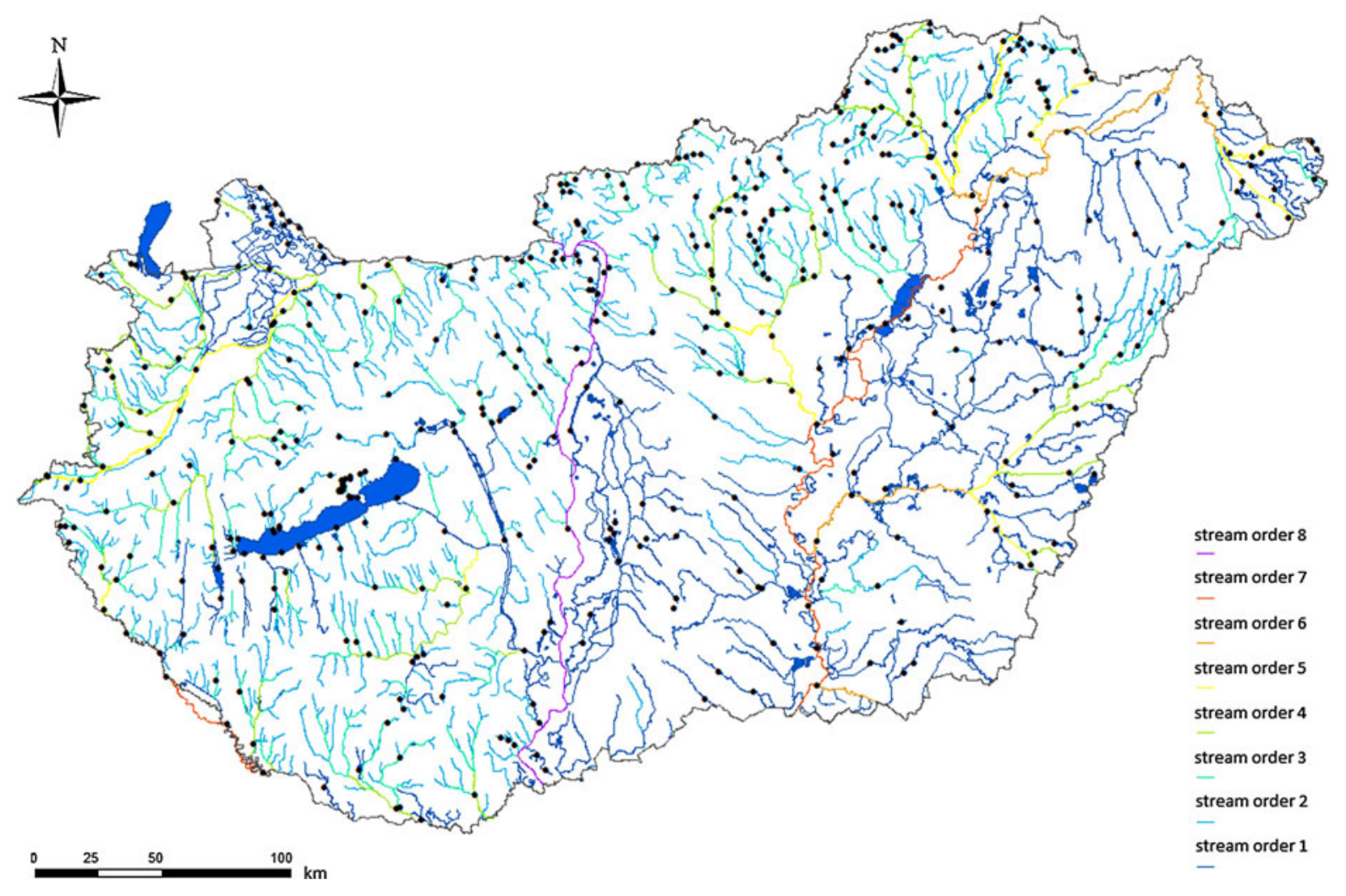

Fig. 1 Map of the sampling sites 
Table 1 Characteristics of the different stream orders in the Pannon Ecoregions, Hungary

\begin{tabular}{lllllllll}
\hline Stream order & 1 & 2 & 3 & 4 & 5 & 6 & 7 & 8 \\
\hline $\begin{array}{l}\text { Number of stream } \\
\text { sites }\end{array}$ & 317 & 128 & 33 & 8 & 3 & 2 & 4 & 11 \\
$\begin{array}{c}\text { Ratio from the total } \\
\text { stream sites (\%) }\end{array}$ & 62.6 & 25.3 & 6.5 & 1.6 & 0.6 & 0.4 & 0.8 & 2.2 \\
$\begin{array}{l}\text { Species } \\
\text { number } \pm \text { SD }\end{array}$ & $23 \pm 7$ & $28 \pm 7$ & $35 \pm 8$ & $33 \pm 5$ & $34 \pm 14$ & $34 \pm 10$ & $43 \pm 6$ & $44 \pm 16$ \\
$\begin{array}{l}\text { Diversity } \pm \text { SD } \\
\text { Evenness } \pm \text { SD }\end{array}$ & $2.73 \pm 0.67$ & $2.95 \pm 0.69$ & $3.21 \pm 0.76$ & $3.14 \pm 0.71$ & $3.27 \pm 0.93$ & $3.11 \pm 0.12$ & $3.61 \pm 0.9$ & $3.75 \pm 0.81$ \\
\hline
\end{tabular}

error $t_{0}=0.013$ ) (Fig. 2A). The evenness values are not seems to be related to the stream order (Fig. 2A). The gradient feature is supported by the principal component projection of the eigenvector of the weight matrix (Fig. 2B). The self-organizing map of water chemistry data showed neither clustering nor gradient tendency in relation to stream order (map size $11 * 5$, final quantization error $q_{0}=0.465$, final topographic error $t_{0}=0.009$ ) (Fig. 3).

The mixed-effects linear models showed that the number of species increased significantly with the increase of stream order (Table 2). At average, 8\% increase in species number was observed per $1 \mathrm{U}$ increase in stream order (Fig. 4A). Post hoc tests indicated that first-order streams had significantly less species than streams with order 2,3,7, and 8, and 2nd streams had less species than eighth-order streams (Fig. 4A). Additionally, a marginally non-significant difference was found between stream orders 2 and $3(P=0.052)$.

A unit increase in stream order is associated with an average of $10.3 \%$ increase in Shannon diversity (Table 2; Fig. 4B). Post hoc tests indicated that the low order streams had significantly lower diversity than the high order streams (Fig. 4B). Additionally, a marginally non-significant difference was found between stream orders 1 and $3(P=0.053)$ and between stream orders 2 and $8(P=0.061)$.

Evenness was not significantly related to stream order (Table 2; Fig. 4C). This was also the case when we compared the two highest stream orders with the rest (difference between these two categories: $b \pm \mathrm{SE}=$ $0.061 \pm 0.049, P=0.219$ ).
A
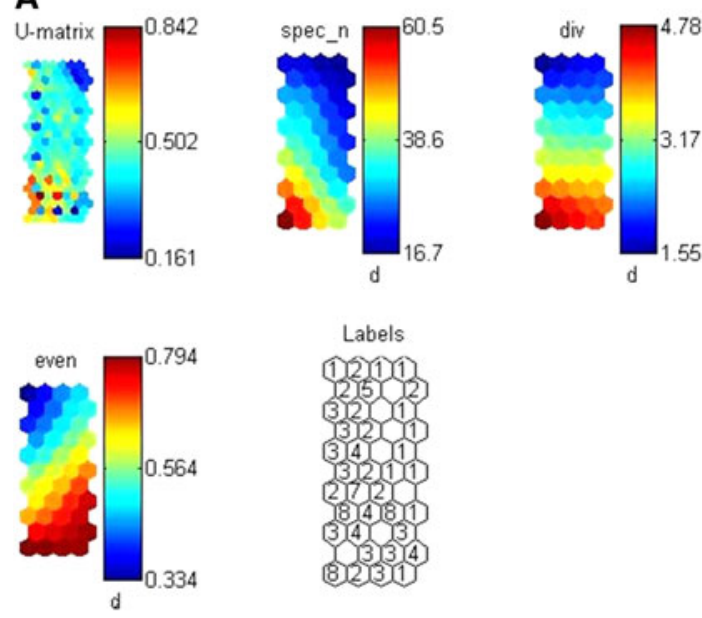

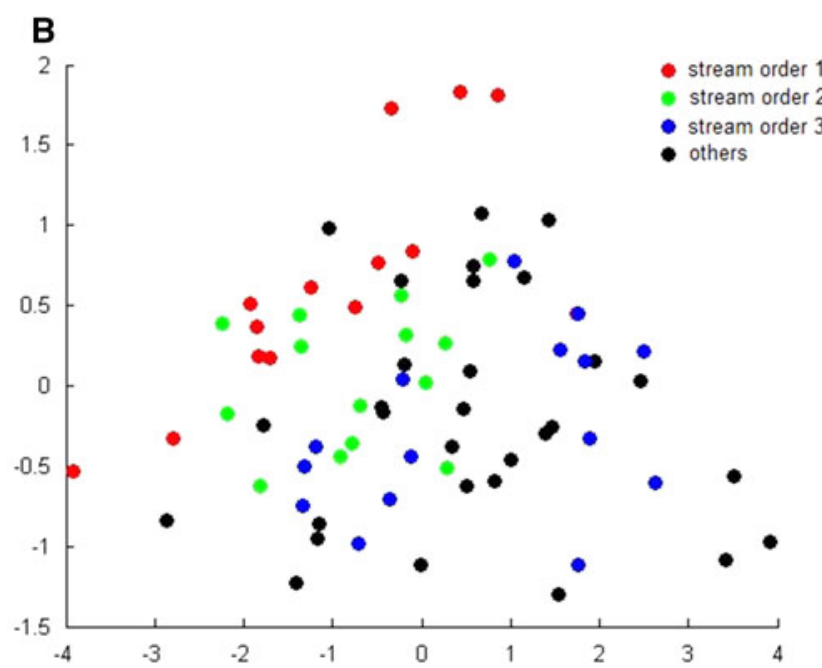

Fig. 2 A Self-organizing map based on species number, diversity, and evenness data. B Principal component projection of the previously descripted data set 
Fig. 3 A self-organizing map based on $\mathrm{NH}_{4}{ }^{+}, \mathrm{NO}_{2}{ }^{-}$, $\mathrm{NO}_{3}{ }^{-}$, and total $\mathrm{P}$ data related to stream order
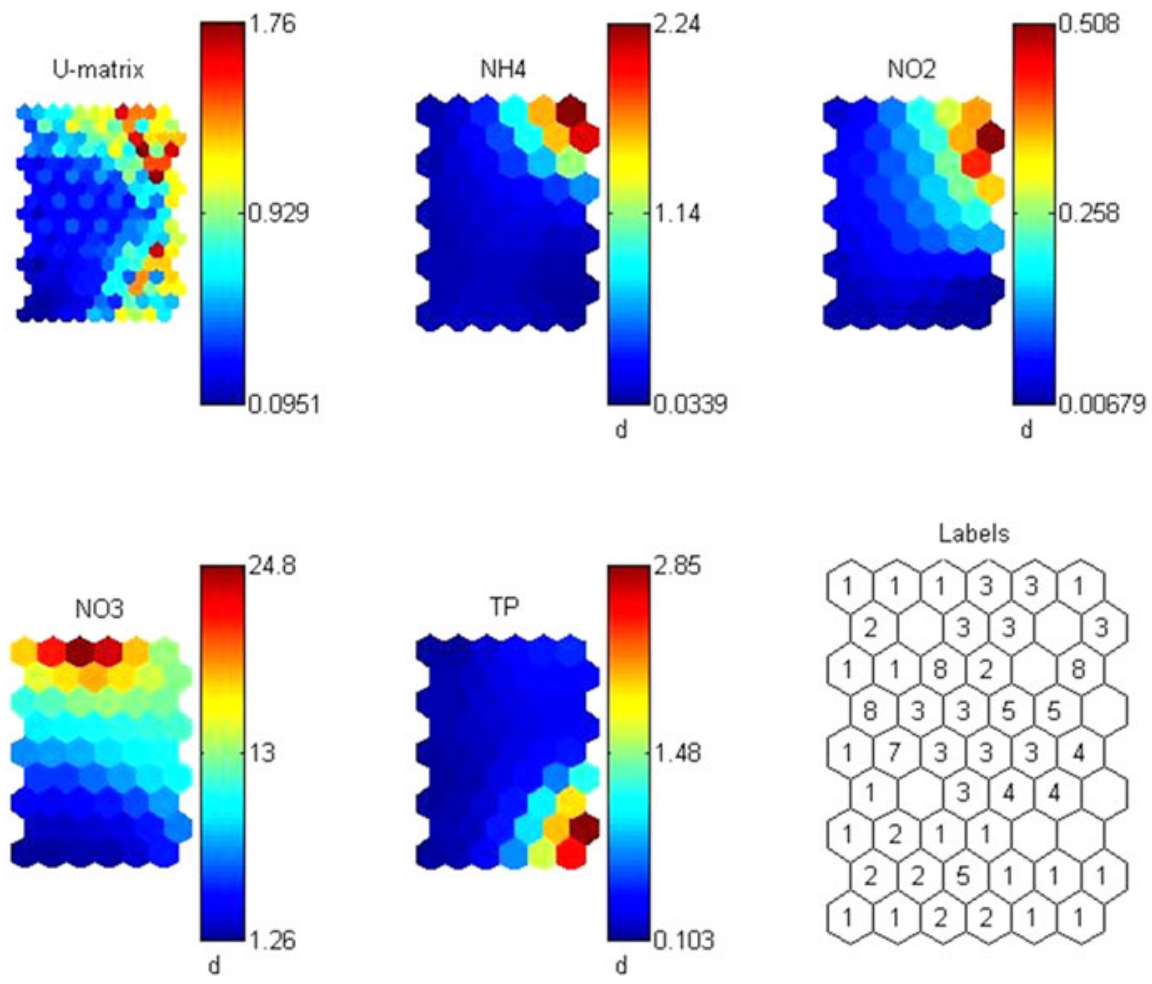

\section{Discussion}

Metrics such as species number and diversity are frequently used in ecological status assessment for explaining spatial and temporal patterns of biotic communities (Borics et al., 2012) to better understand their functioning. Parallel to the release of the WFD, Gray (2000) discussed the need to re-evaluate whether diversity indices alone are useful to detect environmental changes. Recent studies recalled these ideas: diversity would provide a fast and complex overview of the ecological status, since the Shannon index and species richness, as the most widely used diversity metrics, appear to be able to collect information from the bulk of the diatom assemblages (Blanco et al., 2012).

The river continuum concept (RCC) (Vannote \& Sweeney, 1980) separates stream segments by size and location along the river course and therefore serves as measure of position in the river continuum. The catchment area and discharge increase with Strahler order (Hughes \& Omernik, 1983; Hughes et al., 2011) and stream order is also applicable to describe distribution of human activities in the river basin and it was found to be a useful tool in river basin
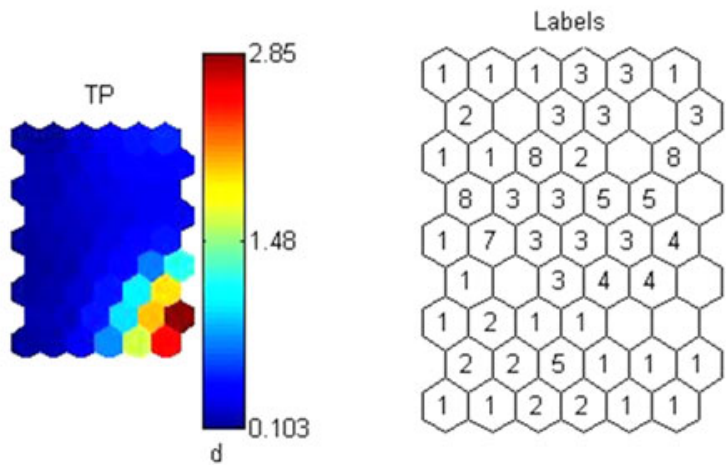

classification in Japan (Miyamoto et al., 2011). Additionally, it is relatively easy to obtain and visualize. Along the river continuum from the first (tiny springbrook) to the highest stream orders (mighty river), a number of biological changes can be observed that are related to the pattern of the energy inputs. The carbon turnover lengths increase in large rivers (Naiman et al., 1988). Functional group composition of the consumers (e.g., macroinvertebrates) basically depends on the resource inputs. The heterotrophic inputs dominate in lower order streams and in large rivers. In mid-order streams, the variation of energy inputs might be the greatest (minimal shading and CPOM, profuse sunlight, and substantial amount of FPOM) consequently it predicts a peak in biological diversity (Allan, 2001). In mayfly and stonefly taxa, diversity values were the highest in 4th to 5th order streams and declined both at lower and higher stream orders due to the physical changes from the source to the mouth and to the geomorphology of the catchment basins (Crunkilton \& Duchrow, 1991). The humpshaped productivity-diversity relationship was supposed to be universal by Huston (1999) since at higher nutrient levels anoxia may delimit diversity. Mean annual respiration rates associated with FPOM, 
Table 2 Results of the mixed-effects linear models

\begin{tabular}{lccccc}
\hline & Value & SE & DF & $t$ value & $p$ value \\
\hline Log (species number) & 0.080 & 0.016 & 148 & 5.081 & 0 \\
Diversity & 0.103 & 0.035 & 148 & 2.970 & 0.0035 \\
Evenness & -0.001 & 0.006 & 148 & -0.0995 & 0.921 \\
\hline
\end{tabular}
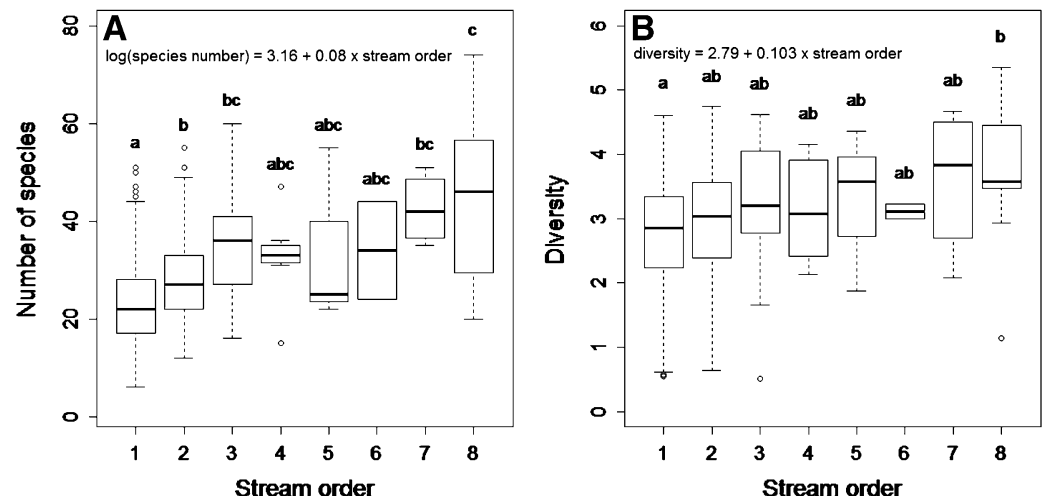

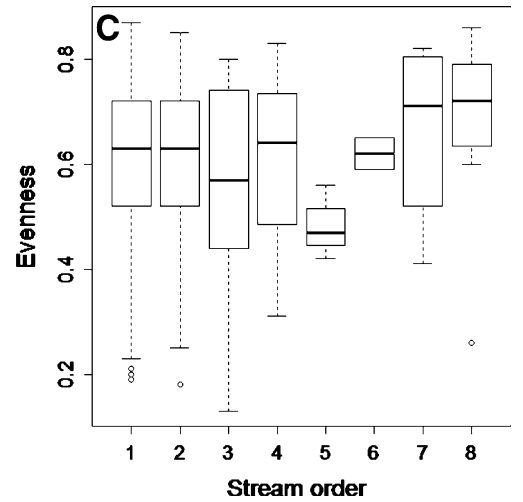

Fig. 4 Relationship between species number, diversity, evenness, and stream orders. Letters above the errorbars mark significant differences in Tukey's post hoc tests (groups with the

percent organic matter, and chlorophyll showed a clear, significant increase with the stream order until the sixth-order streams and then slightly decreased (Naiman, 1983). Diatom species and genus number showed hump-shaped pattern along the $\mathrm{pH}$ (Schneider et al., 2013).

Neither the above pattern nor the humped-shaped relationship appeared in case of benthic diatoms along stream order in the study of Minshall et al. (1983). Rott et al. (1998) found that diatom species composition was arranged well along the stream order in the Grand River, following water quality where the upper part (orders 2-4) of the stream included the clear water sites, the middle part was characterized by highly variable turbidity (orders 4-5), and the lower part of the stream by high silt load (orders 5-6). The tributaries enrich ecosystems in (i) oxidized nitrogen compounds originating from runoff of cultivated areas; (ii) phosphorous; and (iii) ammonium from wastewater treatment in populated areas (Rott et al., 1998). Parallel with the increasing order of the stream the trophic level is also increasing (Vilbaste \& Truu, 2003; Morgan \& Kline, 2011). An increase of the species number and diversity along the course was also found by Szabó et al. (2004). Seyfer \& Wilhm same letters are not different whereas groups with different letters differ significantly). Cursive equations represent regression fits

(1977) supported this relationship from fourth- to sixth-order streams as did Vilbaste \& Truu (2003) from first- to fifth-order streams, but in the latter study they could show only a tendency without statistical support of the differences. However, their multivariate analysis justified that the order of the stream is the master variable for the benthic diatom composition (Vilbaste \& Truu, 2003). Molloy (1992) obtained similar results in three rivers of the Kentucky River system (first- to fifth-order). In two of these rivers Shannon diversity increased from the source to the mouth, and in the third river diversity was the highest at the mouth. Our results are in line with these observations and our original assumption as we found a clear, significant relationship between two of the diversity metrics (species number and Shannon diversity) and the stream order on ecoregion level in first- to eighth-order streams. The species number and the diversity change unequivocally on the stream order gradient.

Though increase of species number and diversity of diatom assemblages along the river continuum seems to be a general phenomenon, disturbances may confuse this regular pattern. The frequency of disturbance can also be a strong driver of diversity patterns 
in streams (Cardinale et al., 2005). Robinson et al. (1994) investigated species number and diversity indices after a wildfire for 4 years. The watershed burnt most seriously showed the biggest changes in the diatom assemblages and no correlation was found between the stream order and diversity metrics.

The relationship between diatom diversity metrics and productivity has remained unclear either because of complex environmental influences or because other variables than nutrients determine diatom diversity (Soininen, 2009). Archibald (1972) found linear negative and Lavoie et al. (2008) found positive relationships between diversity and nutrients, Schneider et al. (2013) between species richness and nutrient (TP), while Bellinger et al. (2006) did not find any significant patterns between them, similar to our results. This is the reason why some authors did not suggest these indices for evaluating ecological conditions (Blanco et al., 2012). In large geographical areas where productivity (assessed by resource supply) can change significantly on a large scale, there is relationship between diversity and productivity (Soininen, 2009). Proceeding to global scales, historical factors explain significantly more of the observed geographic patterns in generic richness than do contemporary environmental conditions (Vyverman et al., 2007).

The second assumption, that species number and diversity values are characteristic for a given stream order, was not supported doubtlessly by our results. However, they show that the diversity metrics of low and high order streams is different. Small, undisturbed streams are characterized by most rapid uptake and transformation of inorganic nitrogen (Peterson et al., 2001), and by high sensitivity to nutrient loading and human alteration (USEPA, 2000), and their species number and diversity is lower. The diatom assemblages of medium fourth- and fifth-order streams are more stable compared with lower order sites based on their variations (Vilbaste \& Truu, 2003), but in our study their values were not significantly different from lower or higher order streams. Diatom assemblages of large rivers differed substantially from those in smaller streams as shown by Winter \& Duthie (2000) because in high order rivers water chemistry indicates not only the geological features of the basin but also the more intensive and extensive land-use characteristics. The effects of these factors on diatom composition are mixed and difficult to separate (Rimet et al., 2004). Furthermore, it has been shown that higher order streams with a greater abundance and variety of food (Lotrich, 1973), bigger habitat size and diffuse pollution (Harrel et al., 1967) support a more diverse assemblage of biota such as fish and macroinvertebrates (Seyfer \& Wilhm, 1977).

The WFD regulates the protection of the surface waters on uniform ecological bases. The member states can involve hydrological and geological factors which have effect on the biota (Kelly et al., 2009a). Considering the structure and function of ecosystems, communities naturally vary on spatial and temporal gradients, which should be taken account also in the status assessment (Kelly et al., 2009b). The recent typology in Hungary does not take the stream order (as hydrological factor and proxy of spatial gradient) into account directly, however, it does consider the size of the watershed. Running waters with a larger watershed are likely to be of higher stream order; therefore, these data are comparable and can be considered in the biological characterization. In a biomonitoring system, stream order is a relevant typological parameter which can basically influence the diatom species number and diversity - which can be supplementary parameters in the ecological status assessment. This thus is an applicable tool for planning biomonitoring programs in such a way as where to avoid over sampling of low- and under sampling of high order streams (Hughes et al., 2011). Equal and high sample number in the different stream orders would enable us to determine characteristic diversity metrics for a given a stream order if we exclude or minimize the gradients of eutrophication, organic and toxic pollution, and even of the hydro-morphological alterations. In this case, the results will be comparable (Kelly et al., 2009a) not only on ecoregion but on European level in the intercalibration exercises following similar sampling practices (Kelly et al., 2012).

Acknowledgments We are grateful to Dr. Veronika Bókony for her help in statistical analyses. The study was supported by the Hungarian National Science Foundation (OTKA K75552) and by EU Societal Renewal Operative Program (TÁMOP4.2.2.A-11/1/KONV-2012-0064).

\section{References}

Allan, J. D., 2001. Stream Ecology. Kluwer, Dordrecht: 388. Archibald, R. E. M., 1972. Diversity and some South African diatom association and its relation to water quality. Water Research 6: 1229-1238. 
Bellinger, B. J., C. Cocquyt \& M. O’Reilly, 2006. Benthic diatoms as indicators of eutrophication in tropical streams. Hydrobiologia 573: 75-87.

Blanco, S., C. Cehudo-Figuerias, L. Tudesque, E. Bécares, L. Hoffmann \& L. Ector, 2012. Are diatom diversity indices reliable monitoring metrics? Hydrobiologia 695: 199-206.

Borics, G., B. Tóthmérész, B. A. Lukács \& G. Várbíró, 2012. Functional groups of phytoplankton shaping diversity of shallow lake ecosystems. Hydrobiologia 698: 251-262.

Cardinale, B. J., M. A. Palmer, A. R. Ives \& S. S. Brooks, 2005. Diversity-productivity relationships in streams vary as a function of natural disturbance regime. Ecology 86: $716-726$.

CEN, 2003. Water Quality - Guidance Standard for the Routine Sampling and Pretreatment of Benthic Diatoms from Rivers. EN 13946:2003. Comité Européen de Normalisation, Geneva: 14.

Crunkilton, R. L. \& R. M. Duchrow, 1991. Use of stream order and biological indices to assess water quality in Osage and Black river basins of Missouri. Hydrobiologia 224: 155-166.

Cushing, C. E., K. W. Cummins, G. W. Minshall \& R. L. Vannote, 1983. Periphyton, chlorophyll- $a$ and diatoms of the Middle Fork of the Salmon River, Idaho. Holarctic Ecology 6: 221-227.

Dunn, W. C., B. T. Milne, R. Mantilla \& V. K. Gupta, 2011. Scaling relation between riparian vegetation and stream order in the Whitewater River network, Kansas, USA. Landscape Ecology 26: 983-997.

EC Parliament and Council, 2000. Directive of the European Parliament and of the Council 2000/60/EC Establishing a Framework for community action in the field of water policy. European Commission PECONS 3639/1/100 Rev 1, Luxembourg.

Garnier, J., G. Billen \& M. Coste, 1995. Seasonal succession of diatoms and Chlorophyceae in the dranage network of the Seine River: observations and modeling. Limnology and Oceanography 40: 750-765.

Gordon, N. D., T. A. McHanon \& B. L. Fintayson, 1994. Stream Hidrology. An Introduction fo Ecologist. Wiley, Chiester: 526.

Gray, J. S., 2000. The measurement of marine species diversity, with an application to the benthic fauna of the Norwegian continental shelf. Journal of Experimental Marine Biology and Ecology 250: 23-49.

Hajnal, É., G. Teke, C. Stenger-Kovács \& J. Padisák, 2010. Information in the biological datasets and the biodiversity estimation on the basis of the Peridat on-line database. CD. 32-36. ISBN 978-615-5018-07-7.

Harrel, R. C., B. J. Davis \& T. C. Dorris, 1967. Stream Order and Species Diversity of Fishes in an Intermittent Stream. Ph.D. thesis, Oklahoma State University: 76.

Higgins, J. V., M. T. Bryer, M. L. Khoury \& T. W. Fitzhugh, 2005. A freshwater classification approach for biodiversity conservation planning. Conservation Biology 19: 432-445.

Hughes, R. M., P. R. Kaufmann \& M. H. Weber, 2011. National and regional comparisons between Strahler order and stream size. Journal of North American Benthological Society 30: 103-121.

Hughes, R. M. \& J. M. Omernik, 1983. An alternative for characterizing stream size. In Fontaine, T. D. \&
S. M. Bartell (eds), Dynamics of Lotic Ecosystems. Ann Arbor Science Publishers, Ann Arbor, Michigan: 87-101.

Huston, M. A., 1999. Local processes and regional patterns: appropriate scales for understanding variation in the diversity of plants and animals. Oikos 86: 393-401.

Kelly, M. G., A. Cazaubon, E. Coring, A. Dell'Uomo, L. Ector, B. Goldsmith, H. Guasch, J. Hürlimann, A. Jarlman, B. Kawecka, J. Kwadrans, R. Laugaste, E. A. Lindström, M. Leitão, P. Marvan, J. Padisák, E. Pipp, J. Prygiel, E. Rott, S. Sabater, H. van Dam \& J. Vizinet, 1998. Recommendations for the routine sampling of diatoms for water quality assessments in Europe. European Journal of Applied Phycology 10: 215-224.

Kelly, M. G., C. Bennett, M. Coste, C. Delgado, F. Delmas, L. Denys, L. Ector, C. Fauville, M. Ferréol, M. Golub, A. Jarlman, M. Kahlert, J. Lucey, B. N. Chatháin, I. Pardo, P. Pfister, J. Picinska-Faltynowicz, J. Rosebery, C. Scgranz, J. Schaumburg, H. van Dam \& S. Vilbaste, 2009a. A comparison of national approaches to setting ecological status boundaries in phytobenthos assessment for the European Water Framework Directive: results of an intercalibration exercise. Hydrobiologia 621: 169-182.

Kelly, M., H. Bennion, A. Burgess, J. Ellis, S. Jugins, R. Guthrie, J. Jamieson, V. Adriaenssens \& M. Yallop, 2009b. Uncertainty in ecological status assessment of lakes and rivers using diatoms. Hydrobiologia 633: 5-15.

Kelly, M. G., C. Gómez-Rodrígez, M. Kahlert, S. F. P. Almeida, C. Bennett, M. Bottin, F. Delmas, J.-P. Descy, G. Dörflinger, B. Kennedy, P. Marvan, L. Opatrilova, I. Pardo, P. Pfister, J. Rosebery \& S. Schneider, 2012. Establishing expectations for pan-European diatom based ecological status assessments. Ecological Indicators 20: 177-186.

Kiss, Zs., 2004. Hét Balaton-felvidéki patak kovaalga flórájának vizsgálata néhány környezeti paraméterrel összefüggésben. MSc Thesis, University of Pannonia, Department of Limnology, Veszprém, Hungary.

Kovács, Zs., 2006. A Víz Keretirányelv néhány tipológiai elemének alátámasztása a magyarországi folyóvizek fizikaikémiai paramétereivel. MSc Thesis, University of Pannonia, Department of Limnology, Veszprém, Hungary.

Kovács, C., Zs. Kiss \& J. Padisák, 2004. Balaton környéki kis vízfolyások diatómáinak florisztikai és mennyiségi vizsgálatai. Hidrológiai Közlöny 84: 65-68.

Kovács, C., J. Padisák \& É. Ács, 2005. A bevonatlakó kovaalgák alkalmazása a hazai kisvízfolyások ökológiai minősítésében. Hidrológiai Közlöny 85: 64-67.

Kutka, F. J. \& C. Richards, 1996. Relating diatom assemblage structure to stream habitat quality. Journal of North American Benthological Society 15: 469-480.

Lavoie, I., S. Campeau, F. Darchambeau, G. Cabana \& J. Dillon, 2008. Are diatoms good integrators of temporal variability in stream water quality? Freshwater Biology 53: 827-841.

Leira, M. \& S. Sabater, 2005. Diatom assemblages distribution in catalan rivers, NE Spain, in relation to chemical and physiographical factors. Water Research 39: 73-82.

Lotrich, V. A., 1973. Growth, production and community composition of fishes inhabiting a 1st, 2nd and 3rd order stream of eastern Kentucky. Ecological Monographs 34: 377-397.

McCormick, F. H., D. V. Peck \& D. P. Larsen, 2000. Comparison of geographic classification schemes for Mid-Atlantic 
stream fish assemblages. Journal of the North American Benthological Society 19(3): 385-404.

Minshall, G. W., R. C. Petersen, K. W. Cummins, T. L. Bott, J. R. Sedell, C. E. Cushing \& R. L. Vannote, 1983. Interbiome comparisons of stream ecosystem dynamics. Ecological Monographs 53: 1-25.

Miyamoto, H., T. Hashimoto \& K. Michioku, 2011. Basin wide distribution of land use and human population: stream order modeling and river basin classification in Japan. Environmental Management 47: 885-898.

Molloy, J. M., 1992. Diatom communities along stream longitudinal gradients. Freshwater Biology 28: 59-69.

Morgan, R. P. \& K. M. Kline, 2011. Nutrient concentrations in Maryland non-tidal streams. Environmental and Monitoring Assessment 178: 221-235.

Naiman, R. J., 1983. The influence of stream size on the food quality of seston. Canadian Journal of Zoology 61: 1995-2010.

Naiman, R. J., H. Décamps, J. Pastor \& C. A. Johnston, 1988. The potential importance of boundaries to fluvial ecosystems. Journal of North American Benthological Society 7: 289-306.

Pan, Y., R. J. Stevenson, B. H. Hill, A. T. Herlihy \& G. B. Collins, 1996. Using diatoms as indicators of ecological conditions in lotic systems: a regional assessment. Journal of North American Benthological Society 15: 481-495.

Peterson, B., W. Wollheim, P. Muholland, J. Webster, J. Meyer \& J. Tank, 2001. Control of nitrogen export from watersheds by the headwater streams. Science 292: 86-90.

Pór, G., Z. Sára, J. Padisák, I. Grigorszky \& Gy. Borbély, 2000. Előzetes vizsgálatok az Aszófói-séd kovaalgáinak felméréséhez. Hidrológiai Közlöny 80: 377-378.

Potapova, M. \& D. F. Charles, 2002. Benthic diatoms in USA rivers: distribution along spatial and environmental gradients. Journal of Biogeography 29: 167-187.

Pringle, C. M., 1985. Effects of chironomid (Insecta: Diptera) tube-building activities on stream diatom communities. Journal of Phycology 21: 185-194.

R Development Core Team, 2010. R: A Language and Environment for Statistical Computing, Reference Index Version 2.11. R Foundation for Statistical Computing,Vienna, Austria. ISBN 3-900051-07-0. http://www.R-project.org. Accessed 20 April 2013.

Rimet, F. \& A. Bouchez, 2012. Biomonitoring river diatoms: implications of taxonomic resolution. Ecological Indicators 15: 92-99.

Rimet, F., L. Ector, H. M. Cauchie \& L. Hoffmann, 2004. Regional distribution of diatom assemblages in the headwater streams of Luxembourg. Hydrobiologia 520: 105-117.

Robinson, C. T., S. R. Rushforth \& W. G. Minshall, 1994. Diatom assemblages of streams influenced by wildfire. Journal of Phycology 30: 209-214.
Rostetter, M., 2009. Magyarországi folyóvizek rendűségi térképe. MSc thesis: 59.

Rott, E., H. C. Duthie \& E. Pipp, 1998. Monitoring organic pollution and eutrophication in the Grand River, Ontario, by means of diatoms. Canadian Journal of Fishery and Aquatic Science 55: 1443-1453.

Schneider, S. C., M. Kahlert \& M. G. Kelly, 2013. Interaction between $\mathrm{pH}$ and nutrients on benthic algae in streams and consequences for ecological status assessment and species richness patterns. Science of the Total Environment 444: 73-84.

Seyfer, J. R. \& J. Wilhm, 1977. Variation with stream order in species composition, diversity, biomass and chlorophyll of periphyton in Otter creek, Oklahoma. The Southern Naturalist 22: 455-467.

Shannon, C. E. \& W. Weaver, 1949. The Mathematical Theory of Communication. University of Illinois Press, Urbana.

Soininen, J., 2009. Is diatom diversity driven by productivity in boreal streams? Diatom Research 24: 197-207.

Strahler, A. N., 1957. Quantitative analysis of watershed geomorphology. Transactions of the American Geophysical Union 38: 913-920.

Szabó, K., K. T. Kiss, L. Ector, M. Kecskés \& É. Ács, 2004. Benthic diatom flora in a small Hungarian tributary of River Danube (Rákos-stream). Archive of Hydrobiologie Supplement Algological Studies 111: 79-94.

USEPA, 2000. Nutrient Criteria Technical Guidance Manual: Rivers and Streams. EPA-822-B-00-002, USEPA, Office of Water, Office of Science and Technology, Washington, DC.

van Dam, H., J. Padisák \& C. Kovács, 2005. ECOSURV BQE Report Phytobenthos. Ministry of Environment and Water, Budapest.

Vannote, R. L. \& B. W. Sweeney, 1980. Geographic analysis of thermal equilibria: a conceptual model for evaluating the effect of natural and modified thermal regimes on aquatic insect communities. American Naturalist 115: 667-695.

Vesanto, J. \& E. Alhoniemi, 2000. Clustering of the self-organizing map. IEEE Transactions on Neural Networks 11: 586-600.

Vilbaste, S. \& J. Truu, 2003. Distribution of benthic diatoms in relation to environmental variables in lowland streams. Hydrobiologia 493: 81-93.

Vyverman, W., E. Verleyen, K. Sabbe, K. Vanhoutte, M. Sterken, D. A. Hodgson, D. G. Mann, S. Juggins, B. Van de Vijver, V. Jones, R. Flower, D. Roberts, V. A. Chepurnov, C. Kilroy, P. Vanormelingen \& A. De Wever, 2007. Historical processes constrain patterns in global diatom diversity. Ecology 88: 1924-1931.

Winter, J. G. \& H. C. Duthie, 2000. Stream epilithic, epipelic and epiphytic diatoms: habitat and use in biomonitoring. Aquatic Ecology 34: 345-353. 